\title{
Optimization and Molecular Characterization of Syngas Fermenting Anaerobic Mixed Microbial Consortium TERI SA1
}

\author{
Ashish Singla ${ }^{a}$, , Sanjiv Kumara, Meeta Lavania ${ }^{a}$, Hemraj Chhipa $^{a}$, Rajkishor \\ Kapardara, Sachin Rastogi ${ }^{a}$, Banwari Lal ${ }^{a, b}$, Priyangshu M. Sarma ${ }^{a, c^{* *}}$
}

aTERI, Darbari Seth Block, India Habitat Centre, New Delhi 110 003, India

${ }^{b}$ TERI University, 10 Institutional Area, Vasant Kunj, New Delhi 110 070, India

${ }^{c}$ ONGC Energy Center, SCOPE Minar, Laxmi Nagar, New Delhi 110092

\begin{abstract}
The present study focused on the optimization and molecular characterization of anaerobic mixed consortium TERI SA1 that can utilize synthesis gas as sole carbon source for volatile fatty acids production. Optimization study using BoxBehnken design and RSM methodology was carried out in order to investigate the effect of three medium factors on metabolite formation from synthesis gas bioconversion: (yeast extract $(0.0-2.0 \mathrm{~g} / \mathrm{L})$, ammonium chloride $(0.0-1.5 \mathrm{~g} / \mathrm{L})$ and corn steep liquor $(0.0-10 \mathrm{~g} / \mathrm{L})$. Optimized parameters enhanced the production of volatile fatty acids upto $3.9 \mathrm{~g} / \mathrm{L}$, which indicated an increase of around $289 \%$ from the non-optimized conditions. Furthermore, two approaches were used for isolation and phylogenetic identification of anaerobic consortium TERI SA1 involving 16S rRNA sequencing of culturable bacterial isolates as well as metagenomic approach (by making a 16S rRNA gene library of total community DNA). Based on similarity search with NCBI database selected positive clones were most closely related with acetogenic microorganisms Clostridium scatalogenes, Clostridium carboxydivorans, Clostridium drakei and Uncultured Clostridium sp. and strains isolated by culturable method (ASH051 and ASH 052) with Clostridium scatalogenes, and Clostridium drakei. These strains have previously been reported for acetic acid production from syngas bioconversion.
\end{abstract}

Keywords: Synthesis gas; Consortium; Volatile fatty acids; Optimization; Characterization.

Article History: Received July $16^{\text {th }}$ 2017; Received in revised form September 13rd 2017; Accepted Sept 28 $8^{\text {th }}$ 2017; Available online How to Cite This Article: Singla, A., Kumar, S., Lavania, M., Chhipa, H., Kapardar, R., Rastogi, S., Lal, B., and Sarma, P.M. (2017) Optimization and Molecular Characterization of Syngas Fermenting Anaerobic Mixed Microbial Consortium TERI SA1.International Journal of Renewable Energy Development, 6(3), 241-251.

https://doi.org/10.14710/ijred.6.3.241-251

\section{Introduction}

Bioethanol production from lignocellulosic biomass by using synthesis gas fermentation is a relatively new technology. This technology combines gasification of nearly all the components of biomass into synthesis gas (also called syngas) which mainly consists of (CO, $\mathrm{H}_{2}$ and $\mathrm{CO}_{2}$ ) and fermentation of syngas components into acetic acid, ethanol and other valuable metabolites using homo-acetogenic organisms. Syngas fermentation process have several advantages than chemical catalytic process such as, higher substrate specificity of biocatalysts, lower energy costs, greater resistance to catalyst poisoning and the lack of requirement for a fixed CO: $\mathrm{H}_{2}$ ratio (Bredwell et al., 1999). Acetogenic microorganisms can reduce $\mathrm{CO}_{2}$ to acetate via the Wood-Ljungdahl pathway or acetyl-CoA pathway. These bacteria are strictly anaerobic and produce acetate as the major fermentation product (Muller, 2003). Homoacetogenic bacteria is capable to produce ethanol from syngas fermentation includes $C$. autoethanogenum, Mesophilic bacterium P7, Alkalibaculum bacchi, Clostridium ljungdahlii, Clostridium drakei, Butyribacterium methylotrophicum, Clostridium ragsdalei, Eubacterium limosum and mixed consortium TERI SA1 among others (Liu et al., 2012; Mohammadi et al., 2012; Singla et al., 2014). So, far syngas bio-conversion was mainly studied using pure cultures or defined cocultures (Lundie and Drake, 1984; Hurst and Lewis, 2010; Kundiyana et al 2011). However, Liu et al (2013) reported the ethanol and acetic acid production from

\footnotetext{
* Corresponding author: priyangshumsarma@gmail.com (P.M. Sarma).
} 
Citation: Singla, A., Kumar, S., Lavania, M., Chhipa, H., Kapardar, R., Rastogi, S., Lal, B., and Sarma, P.M. (2017) Optimization and Molecular Characterization of Syngas Fermenting Anaerobic Mixed Microbial Consortium TERI SA1. Int. Journal of Renewable Energy Development, 6(3), 241-251, doi.org/10.14710/ijred.6.3.241-251

$\mathrm{P}$ a g e $\mid 242$

syngas bioconversion using defined co-culture of strain CP15 and Clostridium propionicum. Hitherto, mixed culture approaches for bioconversion of syngas in to valuable products has been received little attention and microbial community diversity linked to CO conversion was never assessed. Further, optimization of medium is very important step for enhancing metabolites production through microbial interventions (Demain and Davies, 1999; Kennedy and Krouse, 1999). Studies revealed the importance of medium composition in enhancing the overall metabolite production (Klasson et el., 1992; Cotter et al., 2009; Abubackar et al., 2011). Cotter et al., (2009), examined the effect of nitrogenlimited media on ethanol and acetate production using bacterial strains $C$. autoethanogenum and $C$. ljungdahlii. Gaddy and Clausen, (1992) analyzed the effect of yeast extract concentration on product formation during the batch fermentation of $C$. ljungdahlii. A molar ethanol to acetate ratio of 0.11 was achieved at low levels of yeast extract $(0.005,0.01$ and $0.05 \%$ ), whereas this ratio was 0.05 at higher yeast extract concentrations (0.1 and 0.2\%). Moreover, VFAs are valuable chemical compounds and have diverse uses in the market and offers an economically as well as ecologically sustainable platform. They are building blocks for the various valuable organic compounds such as alcohols, aldehydes, ketones, esters and olefins (Fig. $1)$.

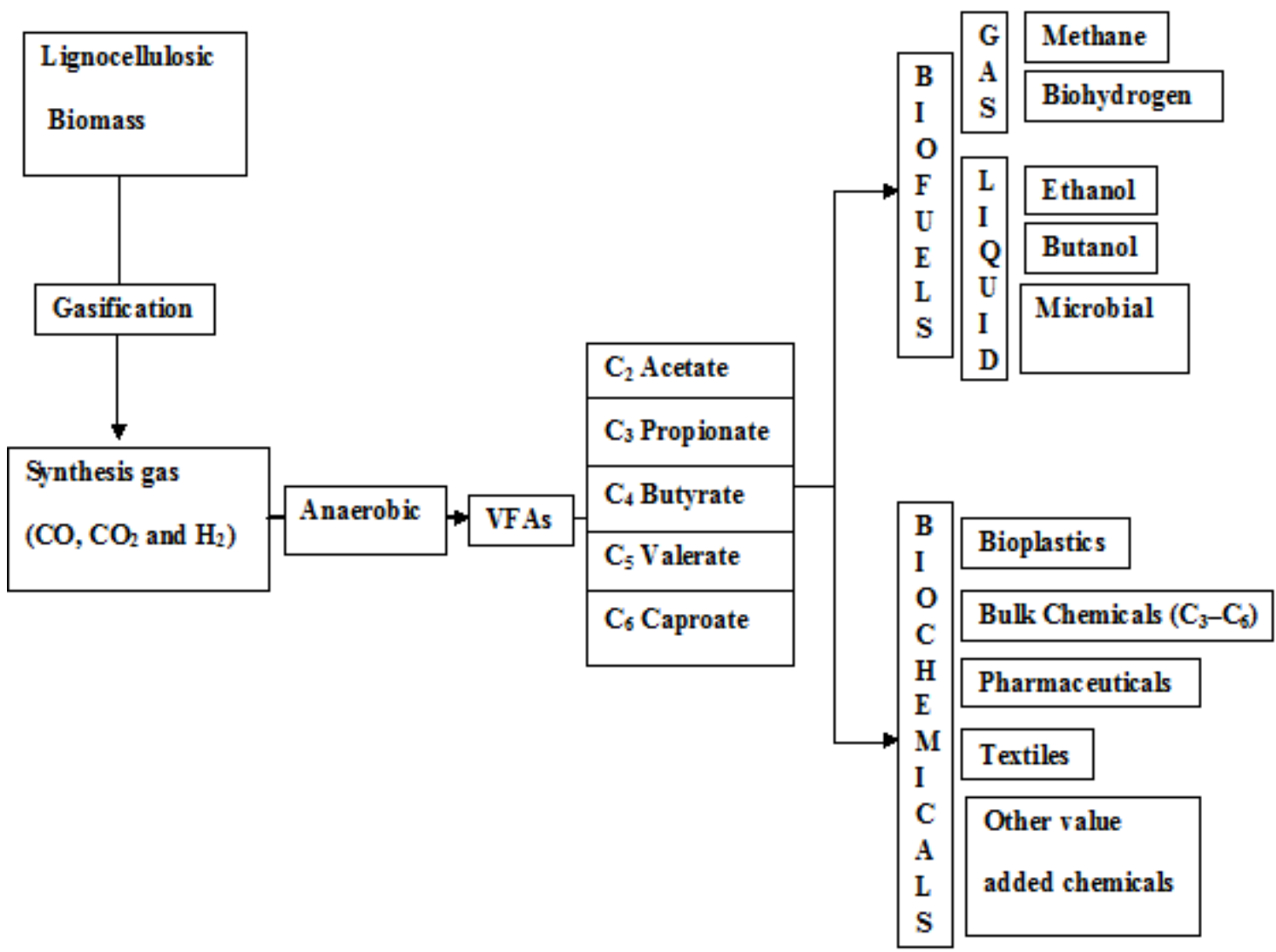

Fig. 1. Conversion of VFAs (volatile fatty acids) into other value-added compounds by biological and chemical means.

The present research was focused on optimization and phylogenetic identification of syngas fermenting mixed microbial consortium TERI SA1 for valuable organic compounds production (i.e., volatile fatty acids) from syngas bioconversion. The effect of different combination of nitrogen sources such as: yeast extract (YE), corn steep liquor (CSL) and ammonium chloride ( $\mathrm{NH} 4 \mathrm{Cl})$ concentration, on syngas bioconversion to ethanol and other valuable products such as volatile fatty acids was also investigated. A two level, Box-
Behnken RSM (response surface methodology) experimental design was employed to estimate the optimum concentration of these parameters that affects syngas bioconversion for enhanced VFAs production. Furthermore, two approaches culturing under anaerobic conditions as well as metagenomic approach (by making 16S rRNA gene library) was used for the isolation and phylogenetic identification of the consortium members. 


\section{Experimental Section}

\subsection{Microorganism and medium composition}

Mixed anaerobic microbial consortium used for this study was enriched from chicken faecal material by growing on Pfennig's basal medium and using syngas as sole carbon source (Singla et al., 2014). Pfennig's basal media (PBM) medium containing (per liter) $50 \mathrm{ml}$ mineral stock solution, $10 \mathrm{ml}$ trace metal stock solution, $10 \mathrm{ml}$ vitamin stock solution, $1 \mathrm{~g}$ yeast extract, $1 \mathrm{ml}$ resazurin $(0.1 \%)$ and $20 \mathrm{ml} \mathrm{L}$-cysteine $\mathrm{HCl}(2.5 \%)$ was used for the initial enrichment of microbial strains. The composition of the mineral, vitamin and trace metal stock solutions has been previously reported (Gaddy and Clausen, 1992). Experimentation work was performed in serum bottles of total volume $130 \mathrm{~mL}$ with $40 \mathrm{~mL}$ of the liquid medium. Anaerobic condition during media preparation was maintained as previously reported by Singh et al. (2014). B-Vitamins solution was added after sterilization. The initial $\mathrm{pH}$ of the medium was adjusted at $6.0 \pm 0.1$ with $2 \mathrm{~N} \mathrm{KOH}$ and $2 \mathrm{~N} \mathrm{HCl}$ solutions. However, solid medium was prepared by adding $1 \%$ glucose as carbon source and $1.5 \%$ agar as solidifying agent in the PBM medium.

\subsection{Experimental system and bioconversion studies adopted for medium optimization}

Anaerobic bottles with a total volume of $130 \mathrm{~mL}$ with $40 \mathrm{~mL}$ working volume were used for experimental purposes. Around one third of the total space of reactor bottle was dispensed with medium and remaining two third was pressurized with syngas. Higher headspace volume allows more gaseous substrate to be available for microbes to utilize. The experimental set-up and the method used for media preparation have been previously described (Singla et al., 2014). The consortium was grown under anaerobic conditions at $150 \mathrm{rpm}$ and $37^{\circ} \mathrm{C}$ in an orbital shaker. Synthetic syngas (Laser gases, New Delhi, India) was provided as carbon source for bacterial growth. 10\% $(\mathrm{v} / \mathrm{v})$ of actively growing culture (grown with only syngas as sole carbon source) was used as inoculum and aseptically transferred to each experimental bottle. 0.5 $\mathrm{mL}$ of gaseous sample collected from reactor bottle headspace was used for analyzing syngas utilization and $2 \mathrm{~mL}$ of liquid sample was periodically withdrawn from each culture bottle (once every $72 \mathrm{~h}$ ) up to $360 \mathrm{~h}$ in order to measure $\mathrm{pH}$, optical density and for analyzing the changes in ethanol, acetic acid and other VFAs concentrations. After collecting liquid as well as gaseous sample, culture bottles were resparged with fresh syngas and maintained with the same headspace pressure of $1 \mathrm{~kg} / \mathrm{cm}^{2}$ and incubated under the same conditions.

\subsection{Experimental design and statistical analysis for medium optimization studies}

Present study also focused on estimating the optimum concentration of nitrogen source that enhances ethanol and VFAs production from syngas bioconversion. A two-level Box-Behnken RSM (response surface methodology) experimental study was done to analyze the effects of different concentration of nitrogen sources; YE (low $0.0 \mathrm{~g} / \mathrm{L}$ and high $2.0 \mathrm{~g} / \mathrm{L}$ ), CSL (low $0.0 \mathrm{~g} / \mathrm{L}$ and high $10 \mathrm{~g} / \mathrm{L}$ ) and $\mathrm{NH}_{4} \mathrm{Cl}$ concentration (low $0.0 \mathrm{~g} / \mathrm{L}$ and high $1.5 \mathrm{~g} / \mathrm{L}$ ) on VFAs and ethanol production from the syngas by mixed consortium TERI SA1 (Table 1).

Table 1

\begin{tabular}{llcc}
\multicolumn{2}{c}{ Range of different factors studied in Box Behnken RSM Design } \\
\hline Factors & Name & -1 & \multicolumn{2}{c}{ Level } \\
\cline { 2 - 4 } & & 0 & 2 \\
\hline $\mathrm{X} 1(\mathrm{~g} / \mathrm{L})$ & Yeast extract & 0 & 10 \\
$\mathrm{X} 2(\mathrm{~g} / \mathrm{L})$ & Corn steep Liquor & 0 & 1.5 \\
$\mathrm{X} 3(\mathrm{~g} / \mathrm{L})$ & Ammonium chloride & 0 & \multicolumn{1}{c}{0} \\
\hline
\end{tabular}

In this study, experimental design and data analysis have been performed using software package Minitab 17 (Minitab Inc. State College, PA, USA) (Table 4). Furthermore, in this study three different variables (CSL, Yeast extract and $\mathrm{NH}_{4} \mathrm{Cl}$ ) were studied with VFAs and ethanol as the response factors. The relationship and interrelationship of the variables was determined by fitting the second-degree polynomial equation to data obtained from 15 run order experiments using mean values of the triplicates (Table 3). All these experiments were set for observations at $3^{\text {rd }}, 6^{\text {th }}, 9^{\text {th }}, 12^{\text {th }}$ and $15^{\text {th }}$ days. The parameters analyzed were ethanol production and VFAs production. The data was analyzed using multiple regressions and a second order polynomial model as given in Equation (1).

$\mathrm{Y}=\beta_{0}+\sum \beta_{\mathrm{n}} \mathrm{X}_{\mathrm{n}}+\sum \beta_{\mathrm{nn}} \mathrm{X}^{2}{ }_{\mathrm{n}}+\sum \beta_{\mathrm{nm}} \mathrm{X}_{\mathrm{n}} \mathrm{X}_{\mathrm{m}}$

Where $Y$ was the predicted response, $\beta 0$ was the intercept coefficient, $\beta \mathrm{n}$ was linear coefficient, $\beta \mathrm{nn}$ was quadratic coefficient and $\beta \mathrm{nm}$ was interaction coefficient. The interactive effects of significant variables were represented in form of contour plots. The response surface interaction and contour plots were generated to understand the interaction among various variables. The statistical significance of the regression coefficient was calculated by Student's ttest. The second order model equation was determined by Fischer's test and the quality of the fit for the polynomial model equation was evaluated by the coefficient of determination $\mathrm{R}^{2}$ (Dalal et al., 2013). 
Citation: Singla, A., Kumar, S., Lavania, M., Chhipa, H., Kapardar, R., Rastogi, S., Lal, B., and Sarma, P.M. (2017) Optimization and Molecular Characterization of Syngas Fermenting Anaerobic Mixed Microbial Consortium TERI SA1. Int. Journal of Renewable Energy Development, 6(3), 241-251, doi.org/10.14710/ijred.6.3.241-251

P a g e $\mid 244$

\subsection{Analytical methods}

The cultures were tested for syngas utilization using gas chromatograph (Agilent-7890A, USA) equipped with thermal conductivity detector (TCD) and a molecular sieve stainless steel packed column (2m X $2 \mathrm{~mm}$ id NUCON, INDIA). Argon gas with the flow rate of $5 \mathrm{~mL} / \mathrm{min}$ along with nitrogen at flow rate of 3 $\mathrm{mL} / \mathrm{min}$ was used as makeup gas. The operational temperatures of the oven, injector and detecting port were kept at 50,100 and $150{ }^{\circ} \mathrm{C}$ respectively. Prior to the analysis, a calibration curve for gases was prepared and $\mathrm{R}^{2}$ value was found to be 0.998 (Singh et al., 2014). The concentrations of VFAs in liquid phase were analysed using same GC equipped with flame ionization detector and DB-WAX column $(30 \mathrm{~m} \times 530$ $\mu \mathrm{m} \times 1 \mu \mathrm{m}$ ) as described by Singh et al., (2014). Helium was used as the carrier gas. The injector and detector temperatures were 220 and $230{ }^{\circ} \mathrm{C}$ respectively. VFA method was calibrated and the calibration curve of each VFA was prepared and $\mathrm{R}^{2}$ value was 0.998 . The bacterial cell growth was monitored by measuring the optical density (OD) at $600 \mathrm{~nm}$ using UV visible spectrophotometer (UV-2450, Shimadzu, Japan). Initial and final $\mathrm{pH}$ was checked by $\mathrm{pH}$ meter (Mettler Toledo, India). The protocol followed for analysis has also been previously described by Singla et al., (2014).

\subsection{Isolation of bacterial strains from mixed consortium TERI SA1}

The authors have enriched mixed consortium TERI SA1 from chicken fecal sample procured from Gwal pahari (Gurgaon, Haryana, $28^{\circ} 28^{\prime} \mathrm{N} 77^{\circ} 1.9^{\prime} \mathrm{E}$ ) India (Singla et al., 2014). To isolate individual bacterial strains from syngas fermenting anaerobic mixed consortium TERI SA1, the enriched culture was serially diluted up to $10^{-5}$ times and $100-\mu l$ aliquots of the diluted bacterial suspension was spread on the specific PBM (Pfennig's basal medium) medium plates with $1 \%$ glucose as carbon source and $1.5 \%$ agar as solidifying agent. Spreading was done in triplicates. Incubation was then carried out for $96 \mathrm{~h}$ at $37^{\circ} \mathrm{C}$ under anaerobic condition in an anaerobic chamber (BactronIV, Shell lab USA). The two distinct bacterial colonies thus obtained were further purified by sub-culturing thrice using same medium and was subsequently identified using 16S rRNA gene analysis based molecular techniques.

\subsection{Molecular characterization using 16S rRNA gene analysis based techniques}

Two approaches were simultaneously used for molecular characterization and phylogenetic identification of syngas fermenting anaerobic mixed consortium TERI SA1. One was the 16S rRNA gene sequencing of bacterial strains isolated using culturable method and another was by making $16 \mathrm{~S}$ rRNA gene library of 33 clones isolated from mixed consortium TERI SA1 for entire bacterial diversity study.

DNA extraction was done using a standard CTAB method for bacterial genomic DNA isolation (Winnepenninckx et al., 1993). 16S rRNA gene was amplified using polymerase chain reaction (PCR) with Taq Polymerase and primers M13F 5'GTAAAACGACGGCCAGT-3' and M13R 5'AACAGCTATGACCATG-3' (Sigma, USA). Gene cloning and selection of positive clones was done using blue/white screening approach. The PCR (polymerase chain reaction) products were subjected to electrophoresis in $0.8 \%$ agarose gels in $1 \mathrm{X}$ TAE buffer (91 V for $30 \mathrm{~min}$ ), and were then analyzed using a Gel Doc system (UVITECH Cambridge, UK). PCR products were purified with the gel purification kit (RBC). Alternatively, the recombinant vector was identified by performing a restriction enzyme digestion to determine the presence of the correct insert.

Nucleotide sequencing was performed using dideoxy termination method (Macrogen, Korea). Identification of bacterial strains was carried out by homology search of the 16S rRNA sequences with the Nucleotide Sequence Data Library (NCBI) using the BLAST $n$ program. The 33 nucleotide sequences obtained from mixed consortium TERI SA1 have been submitted to the Genebank under the accession numbers KR997801 to KR997835 (Table 1). All the sequences were aligned using the Clustal $\mathrm{W}$ program.

\section{Result and Discussion}

\subsection{Optimization of medium parameters for enhancing volatile fatty acids production}

Syngas bioconversion using mixed consortium approach has also been previously studied (Liu et al., 2013; Singla et al., 2014). Nutrients such as nitrogen source, vitamins and sodium have been shown to affect acetogenic metabolism (Lundie and Drake, 1984; Yang and Drake, 1990; Muller, 2003; Saxena and Tanner, 2012). Some of the main medium parameters that enhance metabolite production from syngas bioconversion process are yeast extract, corn steep liquor and ammonium chloride concentration (Gaddy and Clausen, 1992; Guo et al., 2010; Maddipati et al., 2011). Limited availability of some of the essential medium components can cause obstructions in cell metabolism, cofactor formation and intracellular enzyme production. Such condition favors non-growth conditions which divert the metabolic pathway towards solvent formation from acidogenic phase (Klasson et al., 1992; Cotter et al., 2009).

RSM was used to determine the optimum concentration of three factors affecting bioconversion of syngas, maintaining the rest of the variables at a constant level. According to current experimental design, 15 set of experiments were conducted containing three replications at the center point for 
estimating the experimental uncertainty variance in triplicates (Dalal et al., 2013). In present study, three key variables with two concentration levels were studied. Table 1, revealed the three variables and their concentrations at the different coded levels. Table 2 indicated the three variables and their concentrations at different levels of the experimental design and the corresponding response.

Table 2

The Experimental data for the tested process variables at the end of $9^{\text {th }}$ day $(n=3)$

\begin{tabular}{cccccc}
\hline $\begin{array}{c}\text { Run } \\
\text { Orders }\end{array}$ & \multicolumn{3}{c}{ Components } & \multicolumn{2}{c}{ Value added products } \\
\cline { 2 - 6 } & $\begin{array}{c}\text { Yeast extract } \\
\text { (g/L) }\end{array}$ & $\begin{array}{c}\text { Corn steep liquor } \\
\text { (g/L) }\end{array}$ & $\begin{array}{c}\text { Ammonium } \\
\text { chloride (g/L) }\end{array}$ & Ethanol (g/L) & VFAs (g/L) \\
\hline 1 & 2 & 0 & 0.75 & 0.3 & 3.9 \\
2 & 2 & 10 & 0.75 & 0.2 & 2.4 \\
3 & 1 & 0 & 1.5 & 0.15 & 2.6 \\
4 & 0 & 5 & 0 & 0.06 & 2.1 \\
5 & 1 & 5 & 0.75 & 0.05 & 3 \\
6 & 0 & 5 & 1.5 & 0.1 & 3 \\
7 & 1 & 5 & 0.75 & 0.05 & 3.3 \\
8 & 0 & 0 & 0.75 & 0.009 & 2 \\
9 & 1 & 10 & 1.5 & 0.09 & 3.8 \\
10 & 1 & 0 & 0 & 0.05 & 2.3 \\
11 & 2 & 5 & 0 & 0.07 & 3.2 \\
12 & 0 & 10 & 0.75 & 0.06 & 3.4 \\
13 & 1 & 10 & 0 & 0.06 & 3 \\
14 & 2 & 5 & 1.5 & 0.08 & 0.05 \\
15 & 1 & 5 & 0.75 & & 2 \\
\hline
\end{tabular}

\subsection{Main effects plot}

VFAs and ethanol are valuable metabolites synthesized from syngas bioconversion by microbial means. The main effects plot for the studied medium components was shown in Fig. 2. Significant improvement in VFAs production was observed when increasing the YE concentration and concentration of $\mathrm{CSL}$ up to $5 \mathrm{~g} / \mathrm{L}$, whereas increasing $\mathrm{NH}_{4} \mathrm{Cl}$ concentration and CSL concentration above $5 \mathrm{~g} / \mathrm{L}$ did not make a significant impact (Fig. 2a). Similar syngas bioconversion studies have been previously performed suggesting that increasing the YE concentration and CSL concentration results in the increased VFAs production (Maddipati et al., 2011; Gao et al., 2013; Shenkman, 2014). The metabolites production pattern used to stay in the acidogenic phase and did not shift towards solventogenic phase when there was sufficient amount of nutrients or nitrogen source available. As the metabolite, volatile fatty acids (acetic acid, butyric acid, Isobutyric acid, Isovaleric acid, valeric acid and hexanoic acid ), are growth related product and produced in the maximum amount when there was sufficient amount of nutrients available for the growth of bacterial cells (Liggett and Koffler, 1948). YE and CSL besides acting as main nitrogen source also fulfilled other growth requirement of bacterial cells thus pro-longing the growth phase (Liggett and Koffler,
1948) and hence resulted in increased production of VFAs than ethanol. Increasing CSL upto a limited concentration was found to enhance the VFAs production using C.autoethanogenum (Maddipati et al., 2011). In similar way, for selected consortium TERI SA1 higher concentration of CSL (above $5 \mathrm{~g} / \mathrm{L}$ ) negatively affected and was associated with decreased VFAs production (Fig. 2a). One other medium factor studied that effect metabolites production from syngas bioconversion was $\mathrm{NH}_{4} \mathrm{Cl}$, acting as essential mineral component and nitrogen source. But with the studied mixed consortium TERI SA1 there was no significant effect of varying $\mathrm{NH}_{4} \mathrm{Cl}$ concentration on VFAs production, as there was similar amount of VFAs production observed with and without $\mathrm{NH}_{4} \mathrm{Cl}$ (Fig. 2a). This was due to the reason that YE and CSL were capable to fulfill all the nitrogen source and mineral requirements of the bacterial cells and there was no more requirement of $\mathrm{NH}_{4} \mathrm{Cl}$.

Therefore, from the main effects graphical representation it could be interpreted that, YE at the concentration of $2 \mathrm{~g} / \mathrm{L}$ slightly enhanced ethanol production using mixed consortium TERI SA1 (Fig. 2b). This might be due to the minimum growth requirements of bacterial cells for ethanol production. The nutritional requirement by a particular microbial community depends on their metabolic pathway and varies from species to species. Acetogenic bacteria 
Citation: Singla, A., Kumar, S., Lavania, M., Chhipa, H., Kapardar, R., Rastogi, S., Lal, B., and Sarma, P.M. (2017) Optimization and Molecular Characterization of Syngas Fermenting Anaerobic Mixed Microbial Consortium TERI SA1. Int. Journal of Renewable Energy Development, 6(3), 241-251, doi.org/10.14710/ijred.6.3.241-251

P a g e $\mid 246$

develop different metabolic capabilities which might be associated with different medium requirement (Frostl et al., 1996; Silveira et al., 2001). $\mathrm{NH}_{4} \mathrm{Cl}$ showed only a slight change in metabolites concentration due to availability of other two nitrogen sources in sufficient amount. Similar medium optimization studies have been previously done by Gao et al., (2010) who studied the effect of $\mathrm{NH}_{4} \mathrm{Cl}$ on ethanol production with Clostridium autoethanogenum. CSL did not make a significant effect on ethanol production at the concentration of $5 \mathrm{~g} / \mathrm{L}$ and $10 \mathrm{~g} / \mathrm{L}$ (Fig. 2b) as, it has been reported that ethanol is a non-growth related product (Klasson et al., 1992). This might be due to the high cell growth achieved at increased concentrations of CSL due to the presence of additional nutrients such as sugars, vitamins, amino acids, minerals and trace metals in CSL (Liggett and Koffler, 1948). Similar trends have been previously shown by Saxena and Tanner (2012), with Clostridium ragsdalei which observed that using CSL at the concentration of $10 \mathrm{~g} / \mathrm{L}$ leads to reduced ethanol production. Higher concentration of CSL (50 and $100 \mathrm{~g} / \mathrm{L})$ was also inhibitory for cell growth and ethanol production (Savage and Drake, 1986).
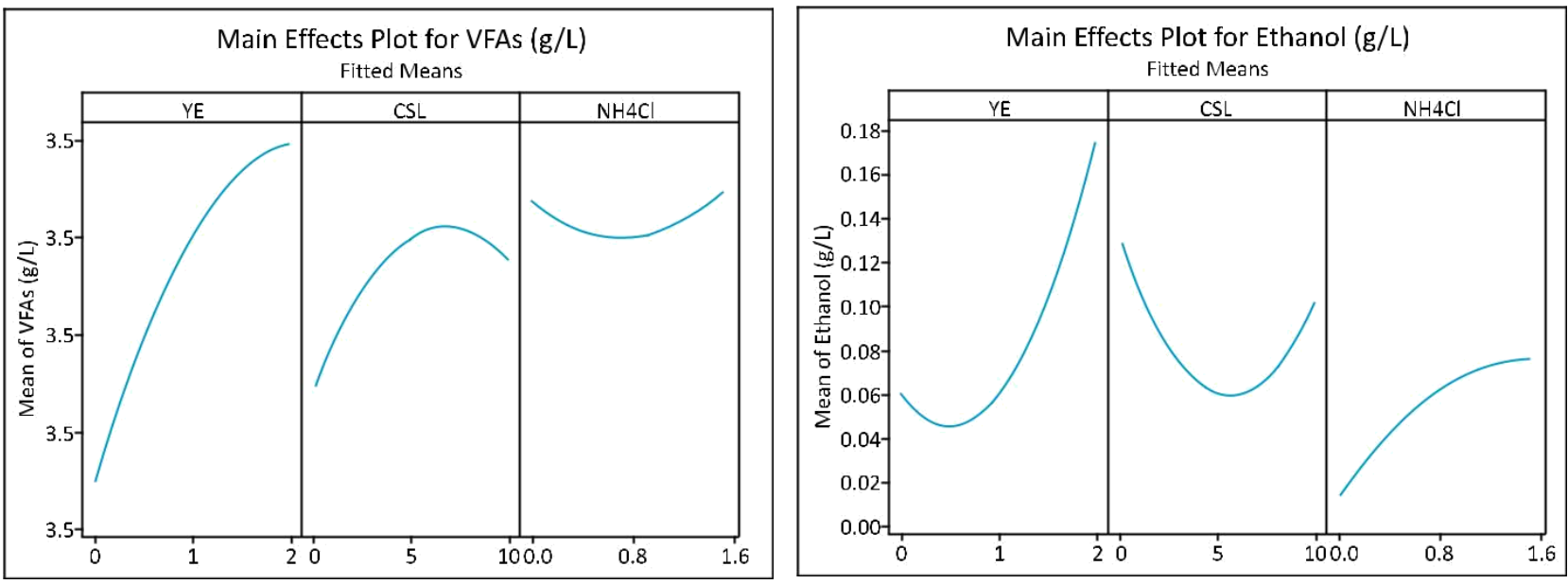

Fig. 2. Main effects plot for (a) VFAs, (b) ethanol.

\subsection{Interaction effects plot}

Graphical representation of interaction effect revealed the mean response at all possible combinations of each two factors studied. For VFAs and ethanol production interaction plot represented that there was a significant positive interaction between YE and CSL as well as between $\mathrm{YE}$ and $\mathrm{NH}_{4} \mathrm{Cl}$ (Fig. 3a and 3b). However, $\mathrm{NH}_{4} \mathrm{Cl}$ did not show any significant interaction with CSL (Fig. 3a and 3b). Maximum amount of VFAs production was observed at yeast extract concentration of $2.0 \mathrm{~g} / \mathrm{L}$ and CSL concentration of around $5.0 \mathrm{~g} / \mathrm{L}$, at both (minimum and maximum) concentrations of $\mathrm{NH}_{4} \mathrm{Cl}$ (Fig.3a). Highest concentration of CSL $(10 \mathrm{~g} / \mathrm{L})$ resulted in decreased VFAs production than at CSL concentration of $5 \mathrm{~g} / \mathrm{L}$, revealing the effect of $\mathrm{YE}(2 \mathrm{~g} / \mathrm{L})$ and limited concentration of CSL (up to $5 \mathrm{~g} / \mathrm{L}$ ) for enhancing VFAs production. It was possible that sufficient amount of nutrients for VFAs production and cell growth were available at higher YE concentration $(2.0 \mathrm{~g} / \mathrm{L})$ and concentration of CSL up to $5.0 \mathrm{~g} / \mathrm{L}$, therefore further increment in any of the nitrogen source did not make significant positive effect on metabolites production (Fig. 3a and 3b). Similar type of study has been previously reported by Kundiyana et al (2010), where maximum acetic acid and ethanol concentration was $4.9 \mathrm{~g} / \mathrm{L}$ and $0.6 \mathrm{~g} / \mathrm{L}$ respectively at midst value of studied CSL concentration. However, higher concentration of VFAs was also observed to be produced at maximum concentration of $\mathrm{YE}$, at midst value of $\mathrm{NH}_{4} \mathrm{Cl} \quad(0.75 \mathrm{~g} / \mathrm{L})$. Therefore, the following interpretation could be make from the study that at highest concentration of $\mathrm{YE}(2 \mathrm{~g} / \mathrm{L}), \mathrm{NH}_{4} \mathrm{Cl}(0.75 \mathrm{~g} / \mathrm{L})$ and CSL $(5 \mathrm{~g} / \mathrm{L})$ were playing supplementary role for each other means $\mathrm{NH}_{4} \mathrm{Cl}$ was no longer required in the presence limited concentration of CSL $(5.0 \mathrm{~g} / \mathrm{L})$ or vice versa.

At high YE concentration, an increase in CSL concentration from $5.0 \mathrm{~g} / \mathrm{L}$ to $10 \mathrm{~g} / \mathrm{L}$ and $\mathrm{NH}_{4} \mathrm{Cl}$ concentration from minimum $(0.0 \mathrm{~g} / \mathrm{L})$ to maximum $(1.5 \mathrm{~g} / \mathrm{L})$ leads to no significant improvement in VFAs production and only slight improvement in ethanol concentration (Fig. $3 \mathrm{a}$ and $3 \mathrm{~b}$ ). It could be easily observed from the interaction plot that at maximum YE concentration of $2.0 \mathrm{~g} / \mathrm{L}$, there was significant improvement in ethanol production with no CSL in the medium (Fig. 3b), confirming that optimum nitrogen requirement of bacterial cell was fulfilled by only increasing the concentration of YE. Interaction between $\mathrm{YE}$ and $\mathrm{NH}_{4} \mathrm{Cl}$ at their highest concentrations, had a significantly positive effect on ethanol production 
(Fig. 3b). Similar trends have been previously reported by Guo et al (2010) with C. autoethanogenum where optimization of $\mathrm{NH}_{4} \mathrm{Cl}$ enhanced final ethanol concentration from $0.06 \mathrm{~g} / \mathrm{L}$ to $0.25 \mathrm{~g} / \mathrm{L}$. Furthermore, increased concentration of $\mathrm{NH}_{4} \mathrm{Cl}$ above midst value $(0.75 \mathrm{~g} / \mathrm{L})$ as well as interaction between CSL and $\mathrm{NH}_{4} \mathrm{Cl}$ did not make any significant impact on ethanol

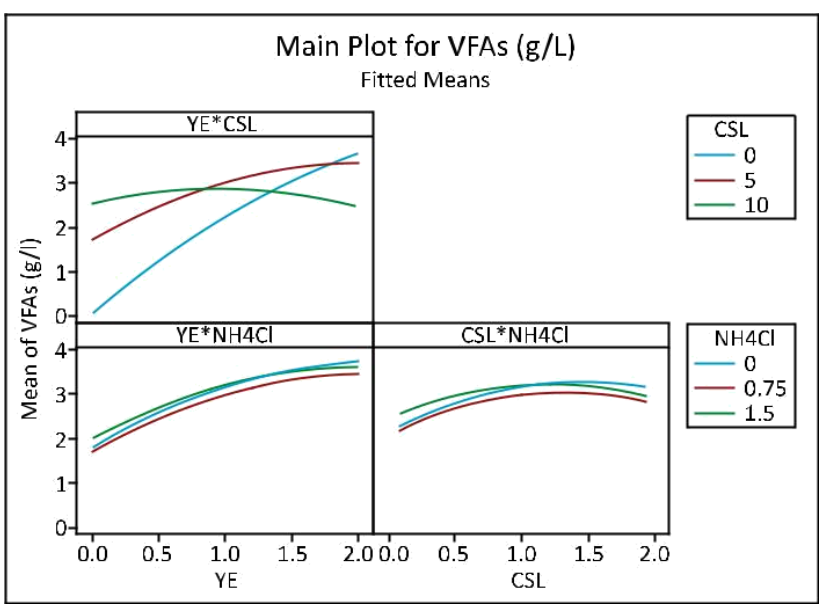

production (Fig. 3b). It could be interpreted by the fact that increase in the CSL concentration (up to $5 \mathrm{~g} / \mathrm{L}$ ) resulted in more supply of nitrogen sources, therefore increment in only VFAs concentration not ethanol concentration (Fig. 3a and 3b).

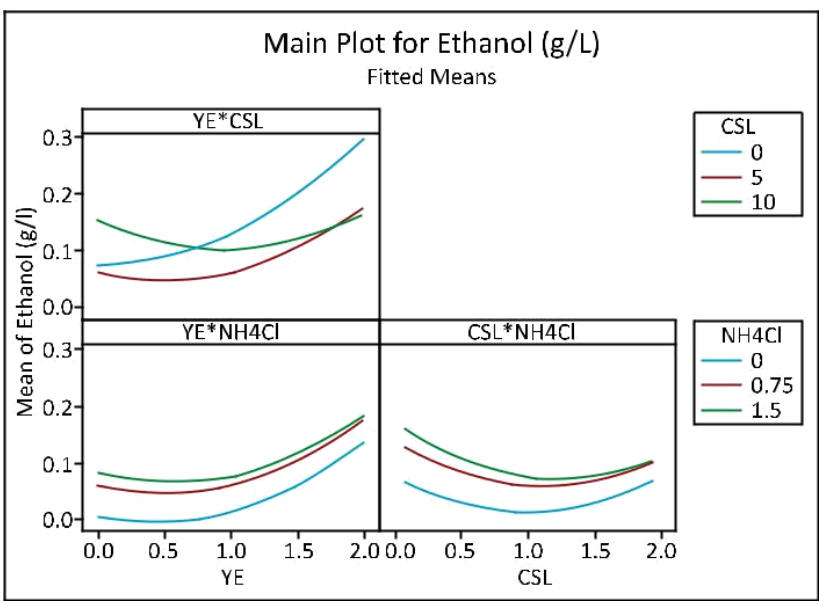

Fig. 3. Interaction effects plots for (a) VFAs, (b) ethanol.

\subsection{Contour effects plot}

The contour plots drown with the help of Minitab 17 software revealed the effect of interaction among the studied components on bioconversion of syngas into ethanol and VFAs. In the present study three sets of contour plots were obtained as presented in Fig. 4 and 5. Figure 4 suggest significant interaction between CSL and $\mathrm{YE}, \mathrm{CSL}$ and $\mathrm{NH} 4 \mathrm{Cl}$ and $\mathrm{NH} 4 \mathrm{Cl}$ and YE. Similar variable patterns were also found in case of ethanol production (Fig. 5).

From the shape of the contour plots, the interaction between the variables could be predicted. Therefore, an elliptical and saddle nature of contours suggested that there was a significant interaction among the variables whereas, circular plots showed negligible interactions (Murthy et al., 2000).
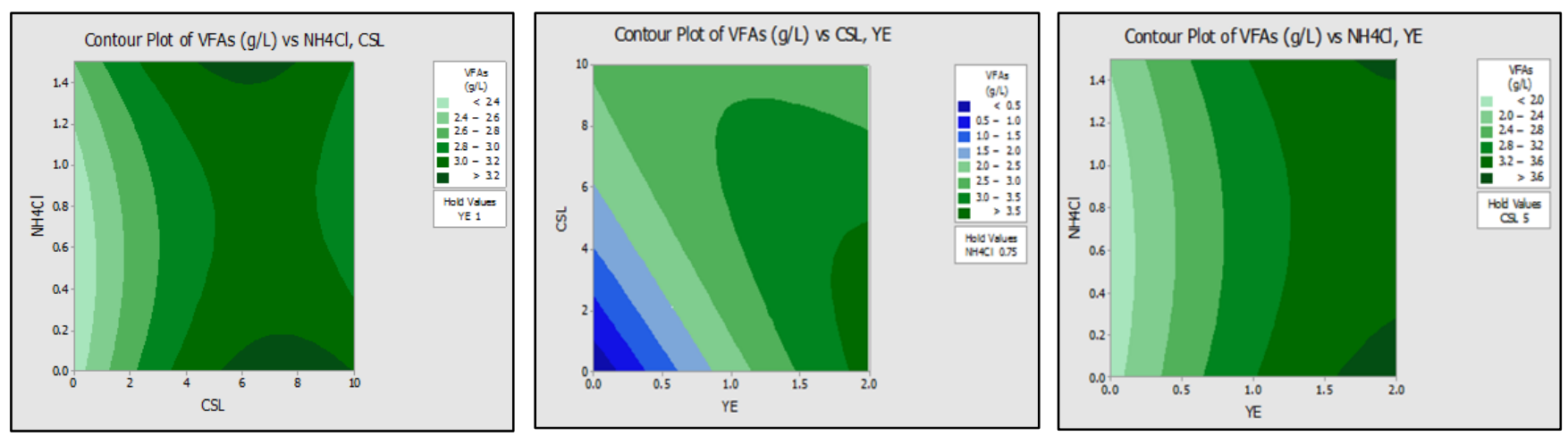

Fig. 4. Contour plots for VFAs production by anaerobic mixed culture TERI SA1, (a) effects of yeast extract and corn steep liquor, (b) effects of yeast extract and ammonium chloride, (c) effects of ammonium chloride and corn steep liquor.

\subsection{Regression analysis and prediction of regression model}

The statistical software was used to evaluate the observed experimental results to derive a regression equation by using an ordinary least square method. From regression equation the statistical significance, direction and magnitude of the relationship between an effect and the response could be predicted (Table 3 and 4). The sign of each regression coefficient indicate the direction of the relationship among the variables. The effects with low p-values are statistically significant (Table 4) (Montgomery, 2003). 
Citation: Singla, A., Kumar, S., Lavania, M., Chhipa, H., Kapardar, R., Rastogi, S., Lal, B., and Sarma, P.M. (2017) Optimization and Molecular Characterization of Syngas Fermenting Anaerobic Mixed Microbial Consortium TERI SA1. Int. Journal of Renewable Energy Development, 6(3), 241-251, doi.org/10.14710/ijred.6.3.241-251

P a g e $\mid 248$

The regression models proposed were as follows:

Ethanol $(\mathrm{g} / \mathrm{L})=0.007+0.003 \mathrm{x}_{1}-0.0111 \mathrm{x}_{2}+0.111 \mathrm{x}_{3}+0.0574 \mathrm{x}_{1} \cdot \mathrm{x}_{1}+0.00220 \mathrm{x}_{2} . \mathrm{x}_{2}-0.0264 \mathrm{x}_{3} . \mathrm{x}_{3}-0.01055 \mathrm{x}_{1} \cdot \mathrm{x}_{2}$

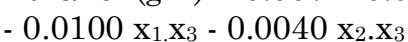

$\operatorname{VFAs}(\mathrm{g} / \mathrm{L})=0.056+2.631 \mathrm{x}_{1}+0.4462 \mathrm{x}_{2}-0.257 \mathrm{x}_{3}-0.384 \mathrm{x}_{1} \cdot \mathrm{x}_{1}-0.01735 \mathrm{x}_{2} . \mathrm{x}_{2}+0.371 \mathrm{x}_{3} . \mathrm{x}_{3}-0.1835 \mathrm{x}_{1} . \mathrm{x}_{2}$ $-0.100 \mathrm{x}_{1} . \mathrm{x}_{3}-0.0333 \mathrm{x}_{2} \cdot \mathrm{x}_{3}$

These regression models were confined for each variable within the following range: (A) YE $=0.0-2.0 \mathrm{~g} / \mathrm{L}$, (B) $\mathrm{CSL}=$ $0.0-10 \mathrm{~g} / \mathrm{L},(\mathrm{C}) \mathrm{NH}_{4} \mathrm{Cl}=0.0-1.5 \mathrm{~g} / \mathrm{L}$.

Table 3

Regression analysis for Ethanol (g/L) versus $\mathrm{NH}_{4} \mathrm{Cl}$, CSL and YE and VFAs versus $\mathrm{NH}_{4} \mathrm{Cl}$, CSL and YE.

\begin{tabular}{lcccccccccc}
\hline Term & \multicolumn{3}{c}{ Total VFAs } & \multicolumn{3}{c}{ Total Ethanol } \\
\cline { 2 - 11 } & Effect & Coeff & SE Coeff & $t$-Value & $p$-Value & Effect & Coeff & SE Coeff & $t$-Value & $p$-Value \\
\hline Constant & & 3.000 & 0.172 & 17.45 & 0.000 & & 0.0600 & 0.0523 & 1.15 & 0.303 \\
$\mathrm{YE}$ & 1.743 & 0.871 & 0.105 & 8.28 & 0.000 & 0.1153 & 0.0576 & 0.0320 & 1.80 & 0.132 \\
$\mathrm{CSL}$ & 0.643 & 0.321 & 0.105 & 3.05 & 0.028 & -0.0272 & -0.0136 & 0.0320 & -0.43 & 0.688 \\
$\mathrm{NH} 4 \mathrm{Cl}$ & 0.050 & 0.025 & 0.105 & 0.24 & 0.822 & 0.0625 & 0.0313 & 0.0320 & 0.98 & 0.374 \\
$\mathrm{YE}^{*} \mathrm{YE}$ & -0.768 & -0.384 & 0.155 & -2.48 & 0.056 & 0.1148 & 0.0574 & 0.0471 & 1.22 & 0.278 \\
$\mathrm{CSL}^{*} \mathrm{CSL}$ & -0.868 & -0.434 & 0.155 & -2.80 & 0.038 & 0.1098 & 0.0549 & 0.0471 & 1.17 & 0.297 \\
$\mathrm{NH}_{4} \mathrm{Cl}{ }^{*} \mathrm{NH} H_{4} \mathrm{Cl}$ & 0.417 & 0.209 & 0.155 & 1.35 & 0.236 & -0.0297 & -0.0149 & 0.0471 & -0.32 & 0.765 \\
$\mathrm{YE}^{*} \mathrm{CSL}$ & -1.835 & -0.918 & 0.149 & -6.16 & 0.002 & -0.1055 & -0.0527 & 0.0453 & -1.17 & 0.296 \\
$\mathrm{YE}^{*} \mathrm{NH}_{4} \mathrm{Cl}$ & -0.150 & -0.075 & 0.149 & -0.50 & 0.636 & -0.0150 & -0.0075 & 0.0453 & -0.17 & 0.875 \\
$\mathrm{CSL}^{*} \mathrm{NH}_{4} \mathrm{Cl}$ & -0.250 & -0.125 & 0.149 & -0.84 & 0.439 & & & & &
\end{tabular}

*YE - yeast extract, $\mathrm{CSL}$ - corn steep liquor, $\mathrm{NH}_{4} \mathrm{Cl}$ - ammonium chloride

Table 4

Analysis of variance for Ethanol (g/L) versus $\mathrm{NH}_{4} \mathrm{Cl}$, CSL and YE and VFAs versus $\mathrm{NH}_{4} \mathrm{Cl}, \mathrm{CSL}$ and YE.

\begin{tabular}{|c|c|c|c|c|c|c|c|c|c|c|c|c|}
\hline \multirow[t]{2}{*}{ Source } & \multicolumn{6}{|c|}{ For VFAs } & \multicolumn{6}{|c|}{ For Ethanol } \\
\hline & $\mathrm{DF}$ & Seq. SS & Adj SS & Adj MS & F-Value & P-Value & DF & Seq. SS & Adj SS & Adj MS & $\begin{array}{c}F- \\
\text { Value }\end{array}$ & $\begin{array}{l}P \text { - } \\
\text { Value }\end{array}$ \\
\hline Linear & 3 & 6.9032 & 6.9032 & 2.30108 & 25.96 & 0.002 & 3 & 0.035863 & 0.035863 & 0.011954 & 1.46 & 0.331 \\
\hline YE & 1 & 6.0726 & 6.0726 & 6.07261 & 68.50 & 0.000 & 1 & 0.026565 & 0.026565 & 0.026565 & 3.24 & 0.132 \\
\hline CSL & 1 & 0.8256 & 0.8256 & 0.82561 & 9.31 & 0.028 & 1 & 0.001485 & 0.001485 & 0.001485 & 0.18 & 0.688 \\
\hline $\mathrm{NH}_{4} \mathrm{Cl}$ & 1 & 0.0050 & 0.0050 & 0.00500 & 0.06 & 0.822 & 1 & 0.007813 & 0.007812 & 0.007812 & 0.95 & 0.374 \\
\hline Square & 3 & 1.4171 & 1.4171 & 0.47237 & 5.33 & 0.051 & 3 & 0.023569 & 0.023569 & 0.007856 & 0.96 & 0.480 \\
\hline YE*YE & 1 & 0.5047 & 0.5473 & 0.54374 & 6.13 & 0.056 & 1 & 0.011096 & 0.012155 & 0.012155 & 1.48 & 0.278 \\
\hline CSL*CSL & 1 & 0.7515 & 0.6947 & 0.69467 & 7.84 & 0.038 & 1 & 0.011656 & 0.011119 & 0.011119 & 1.36 & 0.297 \\
\hline $\mathrm{NH}_{4} \mathrm{Cl} * \mathrm{NH}_{4} \mathrm{Cl}$ & 1 & 0.1609 & 0.1609 & 0.16090 & 1.82 & 0.236 & 1 & 0.000817 & 0.000817 & 0.000817 & 0.10 & 0.765 \\
\hline 2-Way Interaction & 3 & 3.4522 & 3.4522 & 1.15074 & 12.98 & 0.009 & 3 & 0.012255 & 0.012255 & 0.004085 & 0.50 & 0.699 \\
\hline YE*CSL & 1 & 3.3672 & 3.3672 & 3.36723 & 37.99 & 0.002 & 1 & 0.011130 & 0.011130 & 0.011130 & 1.36 & 0.296 \\
\hline $\mathrm{CSL}^{*} \mathrm{NH}_{4} \mathrm{Cl}$ & 1 & 0.0625 & 0.0625 & 0.06250 & 0.71 & 0.439 & 1 & 0.000900 & 0.000900 & 0.000900 & 0.11 & 0.754 \\
\hline Error & 5 & 0.4432 & 0.4432 & 0.14774 & & & 5 & 0.040958 & 0.040958 & 0.008192 & & \\
\hline Lack of Fit & 3 & 0.4432 & 0.4432 & 0.00000 & & & 3 & 0.040958 & 0.040958 & 0.013653 & & \\
\hline Pure Error & 2 & 0.0000 & 0.0000 & & & & 2 & 0.000000 & 0.000000 & 0.000000 & & \\
\hline Total & 14 & 12.2158 & & & & & 14 & 0.112645 & & & & \\
\hline
\end{tabular}

* YE - yeast extract, CSL- corn steep liquor, $\mathrm{NH}_{4} \mathrm{Cl}$ - ammonium chloride 
3.6. Isolation and characterization of culturable bacterial strains from mixed consortium TERI SA1

Analysis of sequences by comparing with known sequences from NCBI database revealed that the two isolates obtained through culturable method under anaerobic conditions had sequence similarities of more than $98.0 \%$ to sequences with Clostridia species. One out of two sequences was $99 \%$ similar to Clostridium scatalogenes and the sequence of the second strain was
99\% similar to that of Clostridium drakei (Table 1). They could be classified according to taxonomic status such as Firmicutes, Clostridia, Clostridiales, Clostridiaceae, and Clostridium. There are previous reports on Clostridium isolated from soil and waste samples that have also been reported for syngas bioconversion into ethanol and acetic acid (Kusel et al 2000; Liou et al 2005).
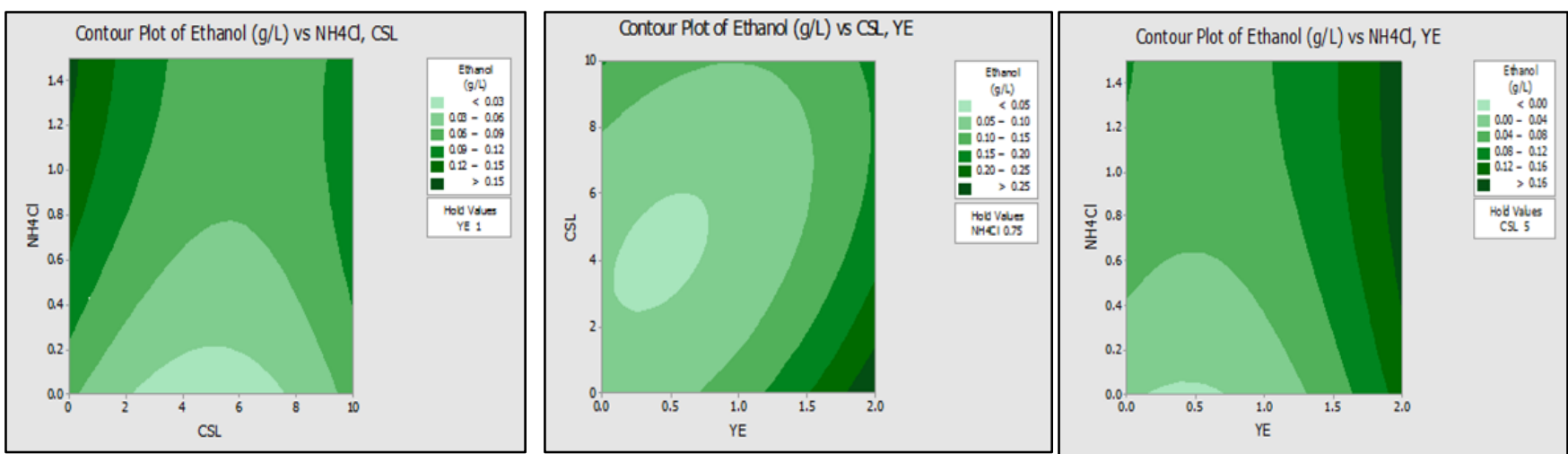

Fig. 5. Contour plots for ethanol production by anaerobic mixed culture TERI SA1, (a) effects of yeast extract and corn steep liquor, (b) effects of yeast extract and ammonium chloride, (c) effects of ammonium chloride and corn steep liquor.

Table 5

Sequence similarity analysis of the isolates obtained from consortium TERI SA1 based on BLASTn comparison to the Genebank database. Culturable method

\begin{tabular}{|c|c|c|}
\hline $\begin{array}{c}\text { Isolates } \\
\text { ASH051 } \\
\text { ASH052 } \\
\text { Metagenomics approach }\end{array}$ & $\begin{array}{c}\text { Closest relative } \\
\text { Clostridium drakei } \\
\text { Clostridium scatalogenes }\end{array}$ & \\
\hline Clones No. & Closest relative & Accession No \\
\hline 1 & Clostridium scatalogenes & KR997801 \\
\hline 2 & Clostridium scatalogenes & KR997802 \\
\hline 4 & Clostridium scatalogenes & KR997804 \\
\hline 5 & Clostridium scatalogenes & KR997805 \\
\hline 6 & Clostridium scatalogenes & KR997806 \\
\hline 7 & Clostridium scatalogenes & KR997807 \\
\hline 8 & Clostridium drakei & KR997832 \\
\hline 10 & Clostridium scatalogenes & KR997808 \\
\hline 11 & Clostridium scatalogenes & KR997809 \\
\hline 15 & Clostridium scatalogenes & KR997810 \\
\hline 18 & Clostridium scatalogenes & KR997811 \\
\hline 20 & Clostridium scatalogenes & KR997812 \\
\hline 21 & Clostridium scatalogenes & KR997833 \\
\hline 22 & Clostridium scatalogenes & KR997813 \\
\hline 24 & Clostridium drakei & KR997814 \\
\hline 25 & Clostridium scatalogenes & KR997815 \\
\hline 26 & Clostridium scatalogenes & KR997815 \\
\hline 27 & Clostridium scatalogenes & KR997816 \\
\hline 28 & Clostridium scatalogenes & KR997817 \\
\hline 29 & Clostridium scatalogenes & KR997818 \\
\hline 30 & Clostridium scatalogenes & KR997819 \\
\hline 31 & Clostridium scatalogenes & KR997820 \\
\hline 32 & Clostridium scatalogenes & KR997821 \\
\hline 33 & Clostridium scatalogenes & KR997822 \\
\hline 34 & Clostridium scatalogenes & KR997823 \\
\hline 35 & Clostridium scatalogenes & KR997824 \\
\hline 36 & Clostridium scatalogenes & KR997825 \\
\hline 37 & Clostridium scatalogenes & KR997826 \\
\hline 38 & Clostridium scatalogenes & KR997827 \\
\hline 39 & Clostridium scatalogenes & KR997828 \\
\hline 40 & Clostridium scatalogenes & KR997829 \\
\hline 41 & Clostridium scatalogenes & KR997830 \\
\hline 50 & Clostridium scatalogenes & KR997831 \\
\hline
\end{tabular}


Citation: Singla, A., Kumar, S., Lavania, M., Chhipa, H., Kapardar, R., Rastogi, S., Lal, B., and Sarma, P.M. (2017) Optimization and Molecular Characterization of Syngas Fermenting Anaerobic Mixed Microbial Consortium TERI SA1. Int. Journal of Renewable Energy Development, 6(3), 241-251, doi.org/10.14710/ijred.6.3.241-251

P a g e $\mid 250$

\subsection{Molecular Characterization and Identification of consortium TERI SA1 by culture independent method}

Thirty three positive clones were selected using a $16 \mathrm{~S}$ rRNA clonal library of the community DNA of consortium TERI SA1 by culture independent method. 16S rRNA sequences from selected positive clones were amplified using M13F and M13R primers and further identified using bioinformatics tools. Comparative analysis of 16S rRNA sequences from an entire community with sequences from Genebank indicated that 31 out of 33 sequences were $99 \%$ similar to Clostridium scatalogenes. However, the remaining two sequences revealed $99 \%$ similarity to Clostridium drakei (Table 5). Several recent reports have documented Clostridium strains from soil and waste samples, which are capable of syngas bioconversion into ethanol and acetic acid (Kusel et al., 2000; Liou et al., 2005). C. scatologenes isolated from soil in 1925, generated acetic acid as the major end product with an optimal growth temperatures of $37{ }^{\circ} \mathrm{C}-40{ }^{\circ} \mathrm{C}$. Furthermore, C. drakei, originally classified as $C$. scatologenes SL1, was isolated from an acidic coal mine pond (Kusel et al., 2000; Liou et al., 2005), was similar to C. carboxidivorans and C. scatologenes and found to have an optimal growth temperature of $37^{\circ} \mathrm{C}$.

As a result, isolation and phylogenetic identification of individual strains from the consortium TERI SA1 indicated that the mixed consortium TERI SA1 either contained only two categories of bacterial strains or there could be additional consortium members which were not discovered from culturable as well as non culturable method used for bacterial identification. Majority of strains from identified members were related to Clostridium scatalogenes while the remainder yielded similarities to Clostridium drakei (Table 5). Moreover, these stains have been previously reported for syngas bioconversion to ethanol and acetic acid (Kusel et al., 2000; Liou et al., 2005; Hurst and Lewis, 2010; Ukpong et al., 2012).

\section{Conclusion}

The present study demonstrated that mixed consortium TERI SA1 was well capable of utilizing syngas for VFAs production. Higher VFAs production was favored at combination of lower $\mathrm{NH}_{4} \mathrm{Cl}$ concentration and higher concentrations of $\mathrm{YE}$ and CSL. A maximum VFAs concentration of $3.9 \mathrm{~g} / \mathrm{L}$ was obtained under the following conditions: $\mathrm{YE}=2.0$ (the maximum value tested), $\mathrm{CSL}=5.0 \mathrm{~g} / \mathrm{L}$ (the midest of value tested) and $\mathrm{NH}_{4} \mathrm{Cl}=0.0 \mathrm{~g} / \mathrm{L}$ (the minimum value tested). VFAs, in turn can be a renewable feedstock and building block for production of various important biofuels and biochemicals for industrial uses. Moreover, phylogenetic identification of the individual strains isolated from consortium TERI SA1 along with molecular characterization of the consortium using culture independent methods indicated the presence of
Clostridium scatalogenes and Clostridium drakei strains.

\section{Acknowledgements}

The financial support for the current research project was provided by Department of Biotechnology, MoST (Ministry of Science and Technology), Government of India. We would also like to thank Department of Biotechnology, Government of India for providing research fellowship to one of the authors.

\section{References}

Abubackar, H.N., Veiga, M.C., Kennes, C. (2011). Biological conversion of carbon monoxide: rich syngas or waste gases to bioethanol. Biofuels Bioprod. Biorefin. 5, 93-114.

Bredwell, M.D., Srivastava, P., Worden, R.M. (1999). Reactor design issues for synthesis-gas fermentations. Biotechnol. Prog. 15, 834-844.

Bruant, G., Lévesque, M.J., Peter. C., Guiot, S.R., Masson, L. (2010). Genomic analysis of carbon monoxide utilization and butanol production by Clostridium carboxidivorans strain P7. PLoS One, 5, 1-12.

Cotter, J.L., Chinn, M.S., Grunden, A.M. (2009). Influence of process parameters on growth of Clostridium ljungdahlii and Clostridium autoethanogenum on synthesis gas. Enzyme Microb. Technol, 44(5), 281-88.

Dalal, J., Sarma, P.M., Mandal, A.K., Lal, B. (2013). Response surface optimization of poly (3-hydroxyalkanoic acid) production using oleic acid as an alternative carbon source by Pseudomonas aeruginosa. Biomass and Bioenrg, 54, 6776.

Demain, A.L., Davies, J.E. (1999). Manual of ind. Microbiol. Biotechnol. $2^{\text {nd }}$ edition. Washington DC: ASM press.

Frostl, J.M., Seifritz, C., Drake, H.L. (1996). Effect of nitrate on the autotrophic metabolism of the acetogens Clostridium thermoautotrophicum and Clostridium thermoaceticum. J. Bacteriol, 178(1), 4597-03.

Gaddy, J.L., Clausen, W.C. (1992). Clostridium ljungdahlii, an Anaerobic Ethanol and Acetate Producing Microorganism. U.S. Patent 5173429.

Gao, J., Atiyeh, H.K., Phillips, J.R., Wikins, M.R., Huhnke, R.L. (2013). Development of low cost medium for ethanol production from syngas by Clostridium ragsdalei. Bioresour. Technol, 147(1), 508-15.

Guo, Y., Xu, J., Zhang, Y., Xu, H., Yuan, Z., Li, D. (2010). Medium optimization for ethanol production with Clostridium autoethanogenum with carbon monoxide as sole carbon source. Bioresour. Technol, 101(22), 8784-89.

Hurst, K.M., Lewis, R.S. (2010). Carbon monoxide partial pressure effects on the metabolic process of syngas fermentation. Biochem. Eng. J. 48, 159-165.

Kennedy, M.J., Krouse, D. (1999). Strategies for improving fermentation medium performance: A Review. J. Ind. Microbial. Biotechnol, 23(6), 456-75.

Klasson, K.T., Ackerson, C.M.D., Clausen, E.C., Gaddy, J.L. (1992). Biological conversion of synthesis gas to fuels. Int. J. Hydrogen Energy, 7(4), 281-88.

Kundiyana, D.K., Huhnke, R.L., Maddipati, P.B., Atiyeh, H.K., Wilkins, M.R. (2010). Feasibility of incorporating cotton seed extract in Clostridium strain P11 fermentation medium during synthesis gas fermentation. Bioresour. Technol, 101(24), 9673-80.

Kundiyana, D.K., Wilkins, M.R., Maddipati, P.B., Huhnke, R.L. (2011). Effect of temperature, $\mathrm{pH}$ and buffer on syngas 
fermentation using Clostridium strain P11. Bioresour. Technol, doi: 10.1016/j.biortech.2011.02.232.

Kusel, K., Dorsch, T., Acker, G., Stackebrandt, E., Drake, H.L. (2000). Clostridium scatologenes strain SL1 isolated as an acetogenic bacterium from acidic sediments. Int. J. Syst. Evol. Microbial, 50, 537-546.

Liggett, R.W., Koffler, H. (1948). Corn steep liquor in microbiology. Microbiol. Molec. Biol. Rev, 12(4), 297-11.

Liou, J.S.C., Balkwill, D.L., Drake, G.R., Tanner, R.S. (2005). Clostridium carboxidivorans sp. nov., a solvent-producing clostridium isolated from an agricultural settling lagoon, and reclassification of the acetogen Clostridium scatologenes strain SL1 as Clostridium drakei sp. nov. Int. J. Syst. Evol. Microbial, 55, 2085-2091.

Liu, K., Atiyeh, H.K., Tanner, R.S., Wilkins, M.R., Huhnke, R.L. (2012). Fermentative production of ethanol from syngas using novel moderately alkaliphilic strains of Alkalibaculum bacchi. Bioresour. Technol. 104, 336-341.

Liu, K., Atiyeh, H.K., Stevenson, B.S., Tanner, R.S., Wilkins, M.R., Huhnke, R.L. (2013). Mixed culture syngas fermentation and conversion of carboxylic acids into alcohols. Bioresour. Technol. 152, 337-346.

Lundie, L.L., Drake, H.L. (1984). Development of a minimally defined medium for the acetogen Clostridium thermoaceticum. J. Bacteriol. 159, 700-03.

Maddipati, P., Atiyeh, H.K., Bellmer, D.D., Huhnke, R.L. (2011). Ethanol production from syngas by Clostridium strain P11 using corn steep liquor as a nutrient replacement to yeast extract. Bioresour. Technol. 102, 6494-6501.

Mohammadi, M., Younesi, H., Najafpour, G.D., Mohamed, A.R. (2012). Sustainable ethanol fermentation from synthesis gas by Clostridium ljungdahlii in a continuous stirred tank bioreactor. J. Chem. Technol. Biotechnol. 87, in press, http://dx.doi.org/10.1002/jctb.3712.

Montgomery, D.C. (2003). Design and analysis of experiments, sixth ed. Wiley and Sons. New York.

Muller, V. (2003). Energy conservation in acetogenic bacteria Appl. Environ. Microbial. 69, 6345-6353.

Murthy, M., Swaminathan, T., Rakshit, S.K., Kosugi, Y. (2000). Statistical optimization of lipase catalyzed hydrolysis of methyloleate by RSM. Bioproc. Biosys. Eng. 22, 35-9.

Savage, M.D., Drake, H.L. (1986). Adaptation of the acetogen Clostridium thermoautotrophicum to minimal medium. $J$. Bacteriol, 165(1), 315-8.

Saxena, J., Tanner, R.S. (2012). Optimization of a corn steep medium for production of ethanol from synthesis gas fermentation by Clostridium ragsdalei. World J. Microbial. Biotechnol. 28, 1553-1561.

Shenkman, R.M. (2014). C. Carboxidovorans culture advances and the effects of $\mathrm{pH}$, temperature, and producer gas on key enzymes. [M.S. thesis], OkState.

Silveira, M.N., Wisbeck, E., Hoch, I., Jonas, R. (2001). Production of glucose-fructose oxidoreductase and ethanol by Zimomonas mobilis ATCC29191 in medium containing corn steep liquor as a source of vitamins. Appl. Microbiol. Biotechnol. 55, 442-45.

Singh, S., Sarma, P.M., Lal, B. (2014). Biohydrogen production by Thermoanaerobacterium thermosaccharolyticum TERI S7 from oil reservoir flow pipeline. Int. J. Hydrogen Energ. 39, 4206-4214.

Singla, A., Verma, D., Lal, B., and Sarma, P.M. (2014). Enrichment and optimization of anaerobic bacterial mixed culture for conversion of syngas to ethanol. Bioresour. Technol. 172, 41-49.

Ukpong, M.N., Atiyeh, H.K., De Lorme, M.J.M., Liu, K., Zhu X., Tanner R.S., Wilkins, M.R., Stevenson, B.S. (2012). Physiological response of Clostridium carboxidivorans during conversion of synthesis gas to solvents in a gas-fed bioreactor. Biotechnol. Bioeng. 109, 2720-2728.
Winnepenninckx, B., Backelgau, T., Wachter, D.R. (1993). Extractions of high molecular weight DNA from molluscs. Trends Genet. 9, 407.

Yang, H.C., Drake, H.L. (1990). Differential effects of sodium on hydrogen- and glucose-dependent growth of the acetogenic bacterium Acetogenium kivui. Appl. Environ. Microbiol. 56, 81-86. 